\title{
The use of antenatal magnesium sulfate for neuroprotection for infants born prematurely Kent Heyborne ${ }^{1,2}$ and Watson A Bowes $\mathrm{Jr}^{3 *}$
}

\begin{abstract}
Addresses: ${ }^{1}$ Maternal and Fetal Medicine, Swedish Medical Center, 501 East Hampden Avenue, Englewood, CO 80110, USA; ${ }^{2}$ University of Colorado Denver, Anschutz Medical Campus, 13001 E 17th Place, Aurora, CO 80045-2570, USA; ${ }^{3}$ University of North Carolina at Chapel Hill, Division of Maternal-Fetal Medicine, UNC Health Care System, 101 Manning Drive, Chapel Hill, NC 27514, USA

* Corresponding author: Watson A Bowes Jr (wbowes@gmail.com)

FI000 Medicine Reports 2010, 2:78 (doi:10.3410/M2-78)

This is an open-access article distributed under the terms of the Creative Commons Attribution-Non Commercial License (http://creativecommons.org/licenses/by-nc/3.0/legalcode), which permits unrestricted use, distribution, and reproduction in any medium, provided the original work is properly cited. You may not use this work for commercial purposes.

The electronic version of this article is the complete one and can be found at: http://f $1000 . c o m / r e p o r t s / m / 2 / 78$

Abstract

Cerebral palsy occurs in three to four infants per 1000 live births. Preterm birth prior to 34 weeks' gestation is a major risk factor. Five randomized controlled trials of antenatal magnesium sulfate $\left(\mathrm{MgSO}_{4}\right)$ found a trend of reduced risk of cerebral palsy and mortality in preterm infants. Three metaanalyses using the data from the five randomized controlled trials, which included a total of 5235 prospectively evaluated fetuses, found that $\mathrm{MgSO}_{4}$ given to women at risk of premature birth significantly reduced the risk of cerebral palsy by $30 \%$ without increasing the risk of perinatal or infant death. The implication for clinical practice is that $\mathrm{MgSO}_{4}$ should be considered for use in patients at high risk of delivery before 34 weeks' gestation.
\end{abstract}

\section{Introduction and context}

The cause of cerebral palsy (CP) is for the most part unknown. CP occurs in three to four infants per 1000 live births, resulting in 800,000 affected individuals in the US. Preterm birth is a major risk factor: $25 \%$ of CP cases occur in the $3.4 \%$ of infants born prior to 34 weeks' gestation. The lifetime economic cost for the care of patients with CP in the US born in 2000 was estimated to be $\$ 11.5$ billion (in 2003 dollars) [1].

The use of magnesium sulfate $\left(\mathrm{MgSO}_{4}\right)$ for seizure prevention in patients with pre-eclampsia and later as a tocolytic agent in premature labor led to serendipitous observations suggesting that infants exposed to $\mathrm{MgSO}_{4}$ in late pregnancy were less likely to develop CP compared with infants born at similar gestational ages who were not exposed to $\mathrm{MgSO}_{4}$ [2-4]. In 1995, Nelson and Grether [5] published the first case-controlled study of the possible neuroprotective effect of $\mathrm{MgSO}_{4}$ on 42 infants (birth weight $<1500 \mathrm{~g}$ ) with moderate or severe CP surviving to age 3 years compared to 75 control infants. The odds ratio for exposure to magnesium during the delivery admission was 0.14 (0.05-0.51).
This effect persisted after control for other tocolytics, steroids, and the indication for $\mathrm{MgSO}_{4}$ treatment [5].

\section{Recent advances}

Subsequent to the study by Nelson and Grether, six other retrospective case-controlled studies were published [6-11], only one of which demonstrated a statistically significant reduction in neurological injury related to maternal $\mathrm{MgSO}_{4}$ treatment [9]. In addition, one of two retrospective cohort studies including a total of 2202 infants found a statistically significant reduction in the odds ratio for untoward neurological outcome $[12,13]$.

As a consequence of the favorable outcome in some of the retrospective studies, five randomized controlled trials were subsequently conducted to assess the hypothesis that antenatal $\mathrm{MgSO}_{4}$ reduces the risk of $\mathrm{CP}$ and mortality in preterm infants (Table 1) [14-18]. Inclusion and exclusion criteria and dosage and timing of $\mathrm{MgSO}_{4}$ varied somewhat among the studies. Primary and secondary neonatal outcomes included, among other things, neonatal death and varying manifestations of neurological injury, including CP. Using endpoints of 
Table I. Randomized controlled trials: effect of magnesium sulfate treatment for expected premature birth on risk of perinatal death or cerebral palsy (CP)

\begin{tabular}{|c|c|c|c|c|c|}
\hline Study & $\begin{array}{l}\text { Country; } \\
\text { no. of location } \\
\text { centers; } \\
\text { no. of countries; } \\
\text { no. of subjects }\end{array}$ & Inclusion & No. of infants & $\begin{array}{l}\text { Regimen: } \\
\text { initial dose; } \\
\text { maintenance }\end{array}$ & $\begin{array}{l}\text { CP RR }(95 \% \mathrm{Cl}) \text {; } \\
\text { combined perinatal } \\
\text { death \& CP } \\
\text { RR }(95 \% \mathrm{Cl})\end{array}$ \\
\hline $\begin{array}{l}\text { MagNET } \\
\text { Mittendorf et al. [14] }\end{array}$ & $\begin{array}{l}\text { US } \\
1 \\
1 \\
149\end{array}$ & $\begin{array}{l}\text { 25-33 weeks } \\
\text { PTL }\end{array}$ & 165 & $\begin{array}{l}4 \mathrm{~g} \\
2-3 \mathrm{~g} / \mathrm{hr} *\end{array}$ & $\begin{array}{l}\text { Not significant (of } n=3 \\
\text { in both treated and } \\
\text { placebo group) } \\
\text { n/a }\end{array}$ \\
\hline $\begin{array}{l}\text { ACTOMgSO } 4 \\
\text { Crowther et al. [I5] }\end{array}$ & $\begin{array}{l}\text { Australia } \\
16 \\
2 \\
1062\end{array}$ & $\begin{array}{l}<30 \text { weeks } \\
\text { Delivery expected } \\
<24 \text { hrs }\end{array}$ & 1255 & $\begin{array}{l}4 \mathrm{~g} / 20 \text { mins } \\
\text { I g/hr (not to exceed } \\
24 \mathrm{hrs} \text { ) }\end{array}$ & $\begin{array}{l}0.85(0.56-I .3 I) \\
0.83(0.66-I .03)\end{array}$ \\
\hline $\begin{array}{l}\text { Magpie Trial } \\
\text { Duley et al. [16] }\end{array}$ & $\begin{array}{l}\text { International } \\
125 \\
19 \\
1544\end{array}$ & $\begin{array}{l}<37 \text { weeks } \\
\text { Severe pre-eclampsia }\end{array}$ & 1593 & $\begin{array}{l}4 \mathrm{~g} / \mathrm{l} 0-15 \mathrm{mins} \\
\mathrm{I} \mathrm{g} / \mathrm{hr} \text { (for } 24 \mathrm{hrs} \text { ) }\end{array}$ & $\begin{array}{l}0.66(0.1 \mathrm{I}-3.94) \\
\mathrm{I} .06(0.09-1.25)\end{array}$ \\
\hline $\begin{array}{l}\text { PREMAG } \\
\text { Marret et al. [17] }\end{array}$ & $\begin{array}{l}\text { France } \\
13 \\
1 \\
573\end{array}$ & $\begin{array}{l}<33 \text { weeks } \\
\text { PTL }\end{array}$ & 688 & $\begin{array}{l}4 \mathrm{~g} / 30 \text { mins } \\
\text { No maintenance }\end{array}$ & $\begin{array}{l}0.70(0.4 I-I .19) \\
0.86(0.55-I .34)\end{array}$ \\
\hline $\begin{array}{l}\text { BEAM } \\
\text { Rouse et al. [18] }\end{array}$ & $\begin{array}{l}\text { US } \\
20 \\
1 \\
224 I\end{array}$ & $\begin{array}{l}\text { 24-3I weeks } \\
\text { High risk of } \\
\text { spontaneous birth }\end{array}$ & 2444 & $\begin{array}{l}6 \mathrm{~g} / 20-30 \text { mins } \\
2 \mathrm{~g} / \mathrm{hr} \text { (for } 12 \mathrm{hrs} \text { ) }\end{array}$ & $\begin{array}{l}0.59(0.40-0.85) \\
0.97(0.77-1.23)\end{array}$ \\
\hline
\end{tabular}

$* 36 \%$ of subjects were more than $4 \mathrm{~cm}$ dilated and received only the loading dose.

In each trial, evaluators of perinatal outcomes were blinded to treatment and all outcomes were based on intention to treat. ACTOMgSO4, Australasian Collaborative Trial of Magnesium Sulfate; BEAM, Beneficial Effects of Antenatal Magnesium Sulfate; Cl, confidence interval; MagNET, Magnesium and Neurologic Endpoints Trial; PTL, preterm labor; RR, relative risk.

perinatal death or CP (to avoid the effect of bias as a result of neonatal death masking the risk of $\mathrm{CP}$ ), some, though not all, of the five trials found a trend of reduced risk of death or $\mathrm{CP}$, though in only one trial, albeit the largest of the five, was the reduction in the risk of $\mathrm{CP}$ statistically significant [18].

To avoid the problem of small sample size, there have been three meta-analyses using the data from the five randomized controlled trials [19-21]. These metaanalyses, which include a total of 5235 prospectively evaluated fetuses, benefit from being robust and homogeneous. The results of these three meta-analyses show convincingly that $\mathrm{MgSO}_{4}$ given to women at risk of premature birth significantly reduces the risk of $\mathrm{CP}$ by $30 \%$ without increasing the risk of perinatal or infant death. The meta-analyses confirm the results of the largest of the randomized controlled trials that assessed the neuroprotective benefit of $\mathrm{MgSO}_{4}$ [18]. CondeAgudelo and Romero [20] calculated that to prevent 1 case of CP, 52 women at risk for preterm delivery at less than 34 weeks' of gestation would have to be treated with $\mathrm{MgSO}_{4}$. In another analysis, Constantine and Weiner [19] estimated that the number needed to treat at less than 32-40 weeks' gestation is 56 and at less than 30 weeks' gestation is 46 .
Because of the varying dose and timing of $\mathrm{MgSO}_{4}$ in the randomized controlled trials, the ideal treatment regimen has not been established. Dosage in the trials varied from a loading dose of $4 \mathrm{~g}$ in 15 minutes to $6 \mathrm{~g}$ in 20 minutes, with maintenance infusion varying from none to $3 \mathrm{~g}$ per hour, and duration of infusion varying from 12 to 24 hours. These studies confirm that the protective effect of $\mathrm{MgSO}_{4}$ occurs when treatment is administered up to 34 weeks' gestation. Only one of the randomized controlled trials included patients randomized beyond 34 weeks' gestation [16]; consequently, the benefit of using $\mathrm{MgSO}_{4}$ beyond 34 weeks' gestation for its neuroprotective effect has not been established. Nor has the neuroprotective effect of $\mathrm{MgSO}_{4}$ been established for multiple gestations, but this may be due to the relatively few number of twin gestations that were included. In the largest trial, though not statistically significant, the risk reduction for twins was of the same magnitude as for singletons [18]. Other important clinical issues that were not addressed consistently in the randomized controlled trials include the use of $\mathrm{MgSO}_{4}$ in conjunction with tocolytic medications for preterm labor and retreatment regimens if delivery does not occur. Addressing the issue of retreatment, the protocol in the Beneficial Effects of Antenatal Magnesium Sulfate (BEAM) trial 
advised repeating the loading dose if at least 6 hours had passed since the discontinuation of the study medication [18]. It is important to emphasize that at low levels antenatal $\mathrm{MgSO}_{4}$ has beneficial neuroprotective effects and does not increase perinatal mortality or morbidity in very preterm infants [22].

The most common lesion associated with CP in infants born prematurely is periventricular white matter injury. The precise mechanism of action for the neuroprotective effect of $\mathrm{MgSO}_{4}$ in preterm infants is not known. Marret et al. [23] and Conde-Agudelo and Romero [20] have summarized the experimental evidence that supports several possible neuroprotective effects of magnesium. The ample biological rationale includes reduction of inflammatory cytokines or free radicals produced during hypoxic-ischemic reperfusion, prevention of excitotoxic calcium-induced injury, membrane stabilization that prevents the persistent membrane depolarization resulting from failure of the $\mathrm{Na}^{+}-\mathrm{K}^{+}$ATP-dependent pump, inhibition of ionotropic glutamate receptors that are involved in injury to pre-oligodendrocytes, stabilization of rapid fluctuations in blood pressure that occur in neonates, and an increase in cerebral blood flow.

No maternal deaths and no life-threatening maternal side effects occurred in the five randomized controlled trials as a result of $\mathrm{MgSO}_{4}$ treatment [20]. Patients exposed to $\mathrm{MgSO}_{4}$ had a $50 \%$ increase of both hypotension and tachycardia compared with control patients. Also, an increased proportion of women receiving $\mathrm{MgSO}_{4}$ had a variety of side effects, including flushing, nausea or vomiting, and sweating, compared with control patients.

\section{Implications for clinical practice}

$\mathrm{MgSO}_{4}$ should be considered for use in patients at high risk of delivery before 34 weeks' gestation, including during planned delivery, premature rupture of membranes, or active labor. Until further studies have determined a minimum effective dose and an optimum time to administer it, a reasonable regimen is a loading dose not exceeding $4 \mathrm{~g}$, followed by a maintenance infusion of 1-2 $\mathrm{g}$ per hour for 24 hours.

Pending further information (secondary analysis of the prevention studies, animal data establishing an effective minimum dose, and so on), we believe a reasonable regimen to administer $\mathrm{MgSO}_{4}$ for neuroprotection includes a $4 \mathrm{~g}$ bolus, $1 \mathrm{~g}$ per hour maintenance infusion, and re-bolus if the $\mathrm{MgSO}_{4}$ has not been administered for more than 6 hours. Given that it takes around 4 hours for $\mathrm{MgSO}_{4}$ levels to reach a steady state in the fetus, we attempt to begin the infusion at least 4 hours prior to birth if possible, but would give it as late as 1 hour prior to birth. The $\mathrm{MgSO}_{4}$ can be discontinued after 12 hours if preterm birth no longer appears imminent. $\mathrm{MgSO}_{4}$ should not be given concurrently with calcium channel blockers. We recommend that, if possible, $\mathrm{MgSO}_{4}$ infusion be postponed for 3-4 hours after the last dose of a calcium channel blocker such as nifedipine. However, if continued tocolysis is deemed necessary, depending on the clinical circumstances, indomethacin might be preferable to a calcium channel blocker.

\section{Abbreviations \\ $\mathrm{CP}$, cerebral palsy; $\mathrm{MgSO}_{4}$, magnesium sulfate.}

\section{Competing interests}

The authors declare that they have no competing interests.

\section{References}

I. Centers for Disease Control and Prevention (CDC): Economic costs associated with mental retardation, cerebral palsy, hearing loss, and vision impairment-United States. 2003. MMWR Morb Mortal Wkly Rep 2004, 53:57-9.

2. Van de Bor M, Verloove-Vanhorick SP, Brand R, Keirse MJ, Ruys JH: Incidence and prediction of periventricular-intraventricular hemorrhage in very preterm infants. J Perinat Med 1987, 15:333-9.

3. Leviton A, Kuban KC, Pagano M, Brown ER, Krishnamoorthy KS, Allred EN: Maternal toxemia and neonatal germinal matrix hemorrhage in intubated infants less than I75I g. Obstet Gynecol 1988, 72:57।-6.

4. Kuban KC, Leviton A, Pagano M, Fenton T, Strassfeld R, Wolff M: Maternal toxemia is associated with reduced incidence of germinal matrix hemorrhage in premature babies. J Child Neurol 1992, 7:70-6.

5. Nelson KB, Grether JK: Can magnesium sulfate reduce the risk of cerebral palsy in very low birthweight infants? Pedatrics 1995 , 95:263-9.

6. O'Shea TM, Klinepeter KL, Dillard RG: Prenatal events and the risk of cerebral palsy in very low birth weight infants. Am J Epidemiol 1998, 15:362-9.

7. Wilson-Costello D, Borawski E, Friedman H, Redline R, Fanaroff AA, Hack M: Perinatal correlates of cerebral palsy and other neurological impairment among very low birth weight children. Pediatrics 1998, 102:315-22.

8. Grether JK, Hoogstrate J, Walsh-Greene E, Nelson KB: Magnesium sulfate for tocolysis and risk of spastic cerebral palsy in premature children born to women without preeclampsia. Am J Obstet Gynecol 2000, 183:717-25.

9. Matsuda Y, Kouno S, Hiroyama Y, Kuraya K, Kamitomo M, Ibara S, Hatae $M$ : Intrauterine infection, magnesium sulfate exposure and cerebral palsy in infants born between 26 and 30 weeks of gestation. Eur J Obstet Gynecol Reprod Biol 2000, 91:159-64.

10. Boyle CA, Yeargin-Allsopp M, Schendel DE, Holmgreen P, Oakley GP: Tocolytic magnesium sulfate exposure and risk of cerebral palsy among children with birth weights less than I,750 grams. Am J Epidemiol 2000, I 52: I20-4.

II. Costantine MM, How HY, Coppage K, Maxwell, RA, Sibai BM: Does peripartum infection increase the incidence of cerebral palsy in extremely low birthweight infants? Am J Obstet Gynecol 2007, 196:e6-8.

12. Schendel DE, Berg CJ, Yeargin-Allsopp M, Boyle CA, Decoufle P: Prenatal magnesium sulfate exposure and the risk for 
cerebral palsy or mental retardation among very lowbirth-weight children aged 3 to 5 years. JAMA 1996, 276: 1805-10.

13. Paneth N, Jetton J, Pinto-Martin J, Susser M: Magnesium sulfate in labor and risk of neonatal brain lesions and cerebral palsy in low birth weight infants. The Neonatal Brain Hemorrhage Study Analysis Group. Pediatrics 1997, 99:EI.

14. Mittendorf R, Dambrosia J, Pryde PG, Lee K-S, Gianopoulos JG, Besinger RE, Tomich PG: Association between the use of antenatal magnesium sulfate in preterm labor and adverse health outcomes in infants. Am J Obstet Gynecol 2002, 186: I I I I-8.

15. Crowther CA, Hiller JE, Doyle LW, Haslam RR; Australasian Collaborative Trial of Magnesium Sulphate (ACTOMg SO4) Collaborative Group: Effect of magnesium sulfate given for neuroprotection before preterm birth: a randomized controlled trial. JAMA 2003, 290:2669-76.

16. Magpie Trial Follow-Up Study Collaborative Group: The Magpie Trial: a randomized trial comparing magnesium sulphate with placebo for pre-eclampsia. Outcome for children at 18 months. BJOG 2007, II 4:289-99.

17. Marret S, Marpeau L, Zupan-Simunek V, Eurin D, Lévêque C, Hellot MF, Bénichou J; PREMAG trial group: Magnesium sulphate given before very-preterm birth to protect infant brain: the randomized controlled PREMAG trial*. BJOG 2007, I I4:3 I0-8.

18. Rouse DJ, Hirtz DG, Thom E, Varner MW, Spong CY, Mercer BM, lams JD, Wapner RJ, Sorokin Y, Alexander JM, Harper M, Thorp JM Jr, Ramin SM, Malone FD, Carpenter M, Miodovnik M, Moawad A, O'Sullivan MJ, Peaceman AM, Hankins GD, Langer O, Caritis SN,
Roberts JM; Eunice Kennedy Shriver NICHD Maternal-Fetal Medicine Units Network: A randomized, controlled trial of magnesium sulfate for the prevention of cerebral palsy. N Engl J Med 2008, 359:895-905.

19. Constantine MM, Weiner SJ; Eunice Kennedy Shriver National Institute of Child Health and Human Development Maternal-Fetal Medicine Units Network: Effects of antenatal exposure to magnesium sulfate on neuroprotection and mortality in preterm infants: a meta-analysis. Obstet Gynecol 2009, I I 4:354-64.

20. Conde-Agudelo A, Romero R: Antenatal magnesium sulfate for the prevention of cerebral palsy in preterm infants less than 34 weeks' gestation: a systematic review and metaanalysis. Am J Obstet Gynecol 2009, 200:595-609.

Changes Clinical Practice

FI000 Factor 8

Evaluated by Watson Bowes 01 Jul 2009

21. Doyle LW, Crowther CA, Middleton P, Marret S: Antenatal magnesium sulfate and neurological outcome in preterm infants: a systematic review. Obstet Gynecol 2009, I I 3:1327-33.

22. Marret S, Marpeau L, Bénichou J: Benefit of magnesium sulfate given before very preterm birth to protect infant brain. Pediatrics 2008, 121:225-6.

23. Marret S, Doyle LW, Crowther CA, Middleton P: Antenatal magnesium suphate neuroprotection in the preterm infant. Semin Fetal Neonatal Med 2007, 12:3 I I-7. 